BOGDAN WALCZAK

Akademia im. Jakuba z Paradyża w Gorzowie Wielkopolskim

ORCID: 0000-0001-8293-0188

\title{
Barwy stów. Studia lingwistyczno-kulturowe, pod redakcją Doroty Filar i Piotra Krzyżanowskiego. Wydawnictwo Uniwersytetu Marii Curie Skło- dowskiej, Lublin 2017, ss. 997
}

Na siedemdziesięciolecie urodzin Profesora Ryszarda Tokarskiego jego uczniowie i współpracownicy poświęcili mu wyjątkowo obszerny (niemal tysiąc stron!) tom studiów zatytułowany Barwy słów. Stosownie do profilu naukowego Jubilata, który należy do najściślejszej czołówki polskich przedstawicieli lingwistyki kulturowej (jest autorem wielu prac o składnikowej analizie znaczenia wyrazów, o teorii pola znaczeniowego, o metaforach i metonimiach, definiowaniu, stereotypach językowych, kognitywizmie, językowym obrazie świata itd., fundamentalnych monografii o strukturze pola znaczeniowego, o znaczeniu słowa i jego modyfikacjach w tekście, o słownictwie jako interpretacji świata, semantyce barw we współczesnej polszczyźnie, wreszcie tomu wykładów z semantyki leksykalnej zatytułowanego Światy za słowami), większość prac mieści się w ramach szeroko pojętej lingwistyki kulturowej i semantyki leksykalnej. W mojej ocenie do tego kręgu należą artykuły Elwiry Bolek, Heleny Borowiec, Magdaleny Danielewiczowej, Anny Dąbrowskiej, Adama Głaza, Jana Hajduka, Małgorzaty Karwatowskiej, Aleksandra Kiklewicza, Bożeny Kotuły, Anny Kozłowskiej, Piotra Krzyżanowskiego, Beaty Kuryłowicz, Jadwigi Linde-Usiekniewicz, Przemysława Łozowskiego, Jolanty Maćkiewicz, Ewy Masłowskiej, Nawoi Mikołajczak-Matyi, Stanisławy Niebrzegowskiej-Bartmińskiej, László Kálmána Nagy’ego, Anny Pajdzińskiej, Haliny Pelcowej, Doroty Piekarczyk, Katarzyny Sadowskiej-Dobrowolskiej, Piotra Stalmaszczyka, Doroty Stanulewicz, Ireny Vaňkovej, Jacka Warchali, Krystyny Waszakowej, Marii Wojtak, Anety Wysockiej, Magdaleny Zawisławskiej czy Doroty Zdunkiewicz-Jedynak.

Są jednak i prace - zwykle przynajmniej częściowo - spoza tego obszaru (a w każdym razie odkrywające, w moim przekonaniu, nowe tereny językowo-kulturowej eksploracji), jak na przykład Barbary Bonieckiej o języku dzieci w wieku przedszkolnym, Renaty Rusin Dybalskiej o medialnym obrazie Polski i Polaków w Czechach, Macieja Grochowskiego o jednostkach funkcyjnych w postaci względnie, Marioli Jakubowicz o etymologii nazw barw w językach słowiańskich, Ewy 
Jędrzejko o grzechach i grzesznikach we frazeologii, paremiologii i aforystyce (polskiej i zapożyczonej), Wojciecha Kajtocha o opowiadaniach Arkadija Strugackiego (autor sam określa swoją pracę mianem analizy historycznoliterackiej), Henryka Kardeli o teorii języka Daniela Dora, Tomasza Korpysza o poetyckim bestiarium Joanny Pollakówny, Józefa Kościa o Porzadku sąów i spraw miejskich jako tekście prawnym, Anny Krzyżanowskiej o wariantywności frazeologicznej na materiale językowym polskim i francuskim, Alicji Pihan-Kijasowej o periodyzacji dziejów polszczyzny północnokresowej, Jadwigi Puzyniny o mowie nienawiści z perspektywy etyki słowa, Adama Siwca o nacechowanych użyciach nazw własnych w memach interetowych, Bogusława Skowronka o mediolingwistyce, Ewy Sławkowej o stylu reportaży Swietłany Aleksijewicz, Kamilli Termińskiej o podstawowych pojęciach hebrajszczyzny biblijnej, Anny Trębskiej-Kerntopf o aforyzmach posługujących się paradoksem, Jerzego Trzebińskiego o układaniu życia w historie (czyli o narratyzacjach), Leszka Tymiakina o repetycji i kreacji jako sposobach uczenia się, Haliny Wiśniewskiej o wyrazach zloto, zloty w barokowych wierszach czy Zofii Zaron o pojęciu OSOBY.

Tom zaleca się dwiema cechami bardzo trudnymi do jednoznacznego osiągnięcia: imponującą różnorodnością i rozmaitością szczegółowych tematów i problemów, a jednocześnie wewnętrzną spójnością, która pozwala na objęcie niemal wszystkich (wyjątki są naprawdę bardzo nieliczne) pomieszczonych w nim prac podtytułem Studia lingwistyczno-kulturowe. Wierzę, iż publikacja znajdzie licznych czytelników - oczywiście w pierwszym rzędzie językoznawców. Myślę, że niektórzy z nich, ci bardziej ortodoksyjni, z pewnym zdziwieniem uświadomią sobie rozległość tematyczną i problemową swojej dyscypliny. No cóż, takie jest współczesne językoznawstwo... 